\title{
The association of periodontal diseases with reproductive pathology
}

\author{
Asocierea afecţiunilor parodontale cu patologia reproductivă
}

\author{
Dragoş Albu ${ }^{1,2,3}$, Alice Albu ${ }^{1,3,4}$, Anca Dumitriu ${ }^{5}$, Paula Perlea ${ }^{6}$ \\ ${ }^{1}$ UMF „Carol Davila“, Bucureşti, România \\ ${ }^{2}$ Spitalul Clinic Filantropia, Bucureşti, România \\ ${ }^{3}$ Centrul de Medicină Materno-fetală şi Reproducere Umană Medlife, Bucureşti, România \\ ${ }^{4}$ Clinica de Endocrinologie şi Diabet, Spitalul Elias, Bucureşti, România \\ ${ }^{5}$ Disciplina de Parodontologie, Facultatea de Medicină Dentară, \\ UMF „Carol Davila“, Bucureşti, România \\ ${ }^{6}$ Disciplina de Endodonţie, Facultatea de Medicină Dentară, UMF „Carol Davila“, Bucureşti, România
}

\begin{abstract}
Introducere. Infertilitatea este o patologie cu frecvenţă în creştere, cu un impact semnificativ asupra calităţii vieţii individului, al cărei tratament continuă să aibă o eficienţă modestă. În consecinţă, abordarea globală a tuturor factorilor implicaţi în patogenia infertilităţii este importantă pentru posibila îmbunătăţire a prognosticului infertilităţii. Sindromul ovarelor polichistice (SOPC) şi endometrioza sunt afecţiuni frecvent întâlnite la pacientele infertile. În ultimii ani, se acumulează date care sugerează că patologia parodontală poate fi asociată cu SOPC şi endometrioza, fiind un posibil contributor în patogenia acestor afecţiuni. De aceea, ne-am propus să efectuăm un studiu care să revizuiască literatura existentă referitor la relaţia dintre afecţiunile parodontale şi SOPC/endometrioză.

Material şi metodă. Articolele publicate în bazele de date Pubmed, Google Scholar şi Web of Science Core Collection au fost revizuite. Au fost incluse doar articolele publicate în limba engleză până în iulie 2019. Am utilizat pentru căutare următoarele cuvinte cheie: afecţiuni parodontale, endometrioză, sindromul ovarelor polichistice.

Rezultate. Asocierea dintre endometrioză şi afectarea parodontală a fost analizată în două studii care au arătat o asociere semnificativă statistic a celor două afecţiuni. Pacientele autodeclarate cu endometrioză în baza de date National Health and Nutrition Examination Survey (NHANES) au avut un risc cu 57\% mai mare de gingivită şi parodontită comparativ cu pacientele nedeclarate cu endometrioză.

Şapte studii caz-control au raportat o asociere între boala parodontală şi SOPC. Pacientele cu SOPC şi afecţiuni parodontale au avut un nivel crescut al interleukinelor proinflamatorii, al hsCRP (high sensitivity C-reactive protein) şi al matrixmetaloproteinazelor. Intervenţia terapeutică pentru SOPC sau pentru parodontite a fost asociată cu un nivel scăzut al markerilor de inflamaţie sistemică.

Concluzii. Deşi studiile existente sunt puţine, datele actuale sugerează o asociere între afecţuni parodontale şi endometrioză/SOPC. Studii ulterioare sunt necesare pentru clarificarea mecanismelor responsabile pentru această asociere, cu posibile implicaţii terapeutice pozitive asupra tratamentului infertilităţii asociate acestor afecţiuni.
\end{abstract}

Cuvinte cheie: parodontite, sindromul ovarelor polichistice, endometrioză

ABSTRACT
Introduction. Infertility is a condition with increasing frequency and a significant impact on the quality of life, whose
treatment continues to have a modest efficiency. As a consequence, the global approach of all possible factors involved
in the pathogenesis of infertility is important for the possible improvement of the prognosis of infertility treatment.
Polycystic ovary syndrome (PCOS) and endometriosis are common disorders in infertile patients. In recent years,
increasing evidence suggest that periodontal disease may be associated with PCOS and endometriosis, being a
possible contributor to the pathogenesis of these disorders. That is why we aimed to perform a review of the existing
literature regarding the relationship between periodontal disease and PCOS / endometriosis.
Material and method. Articles published in Pubmed, Google Scholar and Web of Science Core Collection databases
were reviewed. Only articles published in English until July 2019 were included. The search was performed using the
following keywords: periodontal disease, endometriosis, polycystic ovary syndrome.
Results. The association between endometriosis and periodontal disease was analyzed in two studies that showed a
statistically significant association between the two conditions. Patients self-reported with endometriosis in the National
Health and Nutrition Examination Survey (NHANES) database had a $57 \%$ higher risk of gingivitis and periodontitis
compared to patients not reported with endometriosis.


Seven case-control studies reported an association between periodontitis and PCOS. Patients with PCOS and periodontitis had an increased level of pro-inflammatory cytokines, hsCRP (high sensitivity C-reactive protein) and matrix metalloproteinases. The therapeutic intervention for PCOS or for periodontitis were associated with a lower level of markers of systemic inflammation.

Conclusions. Although there are few existing studies, current data suggest an association between periodontitis and endometriosis / PCOS. Further studies are needed to clarify the mechanisms responsible for this association, with possible positive therapeutic implications on the treatment of infertility associated with these conditions.

Keywords: periodontitis, PCOS, endometriosis

\section{INTRODUCERE}

Sănătatea orală este importantă pentru starea de bine a individului, însă, dincolo de acest aspect, afecţiunile precum boala parodontală par a fi asociate $\mathrm{cu}$ afecţiuni sistemice precum diabetul zaharat de tip 2, bolile cardiovasculare, boli autoimune, naşterea prematură şi întârzierea de creştere intrauterină. Boala parodontală este o boală inflamatorie cronică cauzată de microorganismele de la nivelul plăcii dentare, aproximativ 50\% dintre adulţi având gingivită, 30\% având un grad de parodontită şi aproximativ 5-15\% având parodontită severă (1).

Endometrioza este o inflamaţie mediată hormonal ce afectează 5-10\% dintre femeile de vârstă reproductivă şi $25-30 \%$ dintre pacientele infertile. Sindromul ovarelor polichistice (SOPC) reprezintă cea mai frecventă cauză de infertilitate de cauză endocrină la femei şi prezintă legături reciproce cu sănătatea orală. Astfel, ambele afecţiuni sunt prezente într-o proporţie semnificativă la pacientele care se adresează pentru tratamentul infertilităţii. $\mathrm{Cu}$ toate progresele terapeutice din ultimele decenii înregistrate în medicina reproductivă, eficienţa tratamentului infertilităţii rămâne modestă, în special dacă sunt luate în considerare încărcătura psihologică şi aşteptările acestor paciente. Spre exemplu, cu toate îmbunătăţirile tehnologice din ultimul deceniu, inclusiv cu aplicaţia tehnologiei digitale în evaluarea embrionilor (time-lapse), există circa $30 \%$ embrioni euploizi care nu se implantează. Aceste aspecte îi determină pe specialiştii din domeniul medicinei reproductive să încerce identificarea cât mai detaliată a posibililor contributori la succesul tratamentului infertilităţii. Posibila legătură dintre afecţiunile parodontale şi afecţiunile reproductive precum endometrioza şi SOPC este un aspect care a început să capete recunoaştere, dar care ar putea să ofere perspective încurajatoare în îmbunătăţirea tratamentului infertilităţii la aceste paciente.

\section{OBIECTIVE}

Să evaluăm dacă există o asociere între afecţiunile parodontale şi endometrioză/SOPC prin analizarea datelor existente în literatură.

\section{MATERIAL ŞI METODĂ}

Am efectuat un review al literaturii în 2019, utilizând bazele de date Pubmed, Google Scholar şi Web of Science Core Collection. Cuvintele cheie folosite au fost parodontite, afecţiuni dentare, endometrioză, sindromul ovarelor polichistice. Scrisorile către editor, comentariile, review-urile istorice, raportările de cazuri, articolele nepublicate au fost excluse.

\section{REZULTATE}

Relaţia dintre endometrioză şi boala parodontală a fost analizată în două studii publicate în 2009 (2) şi 2018 (3). Studiul lui Kavoussi şi colab. a analizat transversal 4.136 de femei cu vârste între 18 şi 50 ani şi a arătat că pacientele autodeclarate cu endometrioză au un risc de gingivită şi parodontită cu $57 \%$ mai mare comparativ cu pacientele nedeclarate cu endometrioză (2). În acest studiu, analizând asocierea dintre endometrioză şi cele patru subgrupe de paciente obţinute în funcţie de statusul paradontal, s-a constatat o asociere pozitivă între endometrioză şi afecţiunile orale la pacientele cu gingivită şi la pacientele cu gingivită şi parodontită, comparativ cu grupul sănătos paradontal şi grupul pacientelor cu parodontită fără gingivită (2). În plus, femeile cu afectare parodontală au avut nevoie de un timp cu două luni mai lung pentru a obţine sarcina, comparativ cu pacientele fără afecţiuni parodontale (2).

Studiul lui Thomas şi colab. a analizat 25 de femei cu endometrioză şi 25 fără endometrioză (3) şi a constatat că indicele gingival a fost semnificativ 
mai mare la femeile cu endometrioză, iar proporţia femeilor cu parodontită moderată-severă a fost mai mare (70\%) la femeile cu endometrioză (3).

Relaţia dintre SOPC şi boala parodontală a fost evaluată în şapte studii caz-control. Studiul lui Dursun şi colab. (4) a fost primul studiu care a raportat o prevalenţă mai mare a indicelui plăcii dentare şi a sângerării gingivale la sondare la pacientele cu SOPC comparativ cu grupul control, aspect confirmat şi în studiul lui Rahiminejad şi colab. (5).

Özçaka şi colab. (2012) au evaluat prezenţa TNF- $\alpha$, a receptorilor acestuia şi a IL-6 în lichidul crevicular gingival, în salivă şi în ser la pacientele cu SOPC şi gingivită (30 paciente) şi fără (31 paciente) şi un grup de control (12 paciente) (6). Prezenţa gingivitei a fost asociată cu valori crescute ale IL-6 în ser, saliva şi lichidul crevicular. În schimb, pacientele cu SOPC au avut valori crescute ale TNF alfa în salivă comparativ cu grupul de control. Similar, nivelul IL-17E a fost scăzut la pacientele cu SOPC şi gingivită într-un studiu care a inclus 31 de femei cu SOPC şi gingivită, 30 femei cu SOPC fără gingivită şi 12 femei sănătoase (7). În aceste studii a fost observată o corelaţie între parametrii parodontali (adâncimea şanţului gingival la sondare) şi nivelul seric al interleukinelor IL-17A şi IL-17F (6), TNF- $\alpha$, receptorii de TNF- $\alpha$ şi nivelul salivar de IL6 la pacientele cu SOPC şi gingivită (7).

Alkali şi colab. (2015) au studiat nivelul matrix metaloproteinazei (MMP) 8 şi al inhibitorului tisular al MMP-1 (TIMP-1) în ser şi salivă la 80 de femei cu SOPC şi 45 femei sănătoase (8). În acest studiu, gingivita a fost semnificativ mai frecventă la femeile cu SOPC comparativ cu grupul de control. Autorii au arătat că nivelul salivar şi seric al MMP-8 şi raportul MMP-8/TIMP-1 a fost semnificativ mai mare la femeile cu SOPC independent de prezenţa gingivitei. Nivelul seric şi salivar al MMP8 şi raportul MMP-8/TIMP-1 au fost pozitiv corelate cu adâncimea şanţului gingival la sondare, sângerare gingivală la sondare, indicele plăcii dentare la pacientele cu SOPC, dar nu la cele sănătoase. Nivelul MMP-8 a fost crescut în ser şi salivă la femeile cu SOPC şi la cele cu gingivită (8).

Similar, nivelul seric al MMP-9 şi mieloperoxidaza (MPO) au fost crescute la pacientele cu SOPC şi gingivită comparativ cu cele fără gingivită (9). La pacientele cu SOPC s-a observat o corelaţie po- zitivă între parametrii parodontali clinici şi nivelul seric al MMP-9 şi nivelul salivar al MPO, elastaza neutrofilă (NE) şi MMP-9/TIMP-1 (9).

În studiul lui Varadan şi colab. (10) au fost analizate 60 de femei împărţite în două grupuri egale, SOPC şi control, din punctul de vedere al parametrilor parodontali: adâncimea şanţului gingival la sondare, indicele plăcii, indicele gingival modificat şi sângerarea gingivală la sondare. S-a constatat că femeile cu SOPC au fost semnificativ diferite în ceea ce priveşte indicele gingival modificat şi indicele plăcii comparativ cu grupul control $(\mathrm{p}<0,05)$. Nivelul malondialdehidei în ser şi în lichidul gingival crevicular a fost semnificativ diferit în cele două grupuri. Sângerarea gingivală la sondare şi indicele gingival modificat au fost pozitiv corelate cu nivelul seric al malondialdehidei. S-a constatat că nivelul inflamaţiei gingivale a fost semnificativ mai mare la pacientele cu SOPC comparativ cu grupul control.

Akcali şi colab. (11) au analizat dacă patogenii parodontali şi anticorpii serici îndreptaţi împotriva acestora sunt crescuţi la pacientele cu SOPC. Grupul de studiu a inclus 45 de femei cu SOPC fără patologie parodontală, 35 de femei cu SOPC şi gingivită, 25 de femei fără patologie sistemică sau parodontală, 20 de femei fără SOPC, dar cu gingivită. Au constatat că nivelul salivar al Porphyromonas gingivalis, Fusobacterium nucleatum, Streptococcus oralis şi Tannerella forsythia a fost crescut la femeile cu SOPC faţă de cele fără SOPC, în special în prezenţa gingivitei. Prezenţa SOPC a fost asociată cu un nivel crescut al anticorpilor antiPorphyromonas gingivalis, anti-Prevotella intermedia şi anti-Streptococcus oralis la pacientele cu gingivită. Inflamaţia gingivală a fost pozitiv corelată cu nivelul bacteriilor în salivă la pacientele cu SOPC.

Un studiu care a cuprins 126 de participanţi a arătat că pacientele cu SOPC nou diagnosticate au avut mai frecvent sângerarea gingivală la sondare, un nivel crescut al adâncimii şanţului gingival la sondare şi al nivelului de ataşament, al high sensitivity C-reactive protein (hsCRP) şi o prevalenţă crescută a parodontitei comparativ cu grupul de control şi pacientele tratate cu SOPC (Porwal 2014). Pacientele nou diagnosticate cu SOPC au avut o probabilitate de 2,88 ori mai mare de a avea parodontită moderată. De asemenea, sângerarea 
gingivală la sondare şi nivelul de ataşament au fost semnificativ asociate cu nivelul seric al hsCRP după ajustare pentru factorii de confuzie, cu ambele variabile atât ca predictori, cât şi ca variabile dependente (12).

Deepti şi colab. (13) au evaluat efectul terapiei nonchirurgicale pentru parodontită şi al terapiei medicamentoase (mioinozitol) asupra nivelului seric al hsCRP şi al rezistenţei la insulină la femeile cu SOPC şi parodontită cronică (13). Pacientele care au primit şi tratament parodontal nonchirurgical au avut parametrii parodontali semnificativ îmbunătăţiţi comparativ cu grupul care a primit doar tratament medicamentos. De asemenea, hsCRP şi indicele de insulinorezistenţă HOMA au fost reduse semnificativ în ambele grupuri la 3 şi 6 luni de urmărire, deşi reducerea hsCRP a fost mai mare în grupul tratat cu ambele terapii comparativ cu cel tratat doar cu mioinozitol.

O prezentare de caz publicată în 2014 (14) a arătat că o pacientă cu SOPC şi inflamaţie gingivală a prezentat receptori de estrogeni, dar nu de progesteron la nivelul ţesutului gingival, sugerând că prezenţa acestor receptori ar putea media apariţia leziunilor gingivale în SOPC.

În studiul lui Pavlatou, s-a remarcat o tendinţă de corelare a gingivitei inflamatorii (indicele gingival) înainte de fertilizarea in vitro (FIV) cu numărul de ovocite obţinute după stimularea ovariană (r = $-0,26 ; p=0,04)$ şi cu numărul de embrioni de bună calitate obţinuţi după FIV (15).

\section{DISCUȚII}

\section{Endometrioza şi parodontita}

Endometrioza este o afecţiune estrogen-mediată caracterizată prin prezenţa glandelor şi a stromei endometriale în afara cavităţii uterine. Din punct de vedere patogenic, endometrioza este caracterizată printr-o inflamaţie sistemică cronică. Se consideră că, printre multitudinea de factori implicaţi în persistenţa ţesutului endometriotic ectopic, un factor care contribuie decisiv este defectul capacităţii sistemului imunitar de a inactiva fluxul menstrual retrograd.

Deşi doar două studii au analizat asocierea bolii parodontale cu endometrioza, unul dintre acestea a analizat 4.136 de femei cu vârste cuprinse între 18 şi 50 ani incluse în cohorta National Health and
Nutrition Examination Survey (NHANES) în perioada 1999-2004. În acest studiu, s-a constatat că femeile cărora li s-a spus că au endometrioză prezintă o probabilitate cu $57 \%$ mai mare de a avea parodontită comparativ cu pacientele fără endometrioză. În consecinţă, deşi numărul studiilor este redus, numărul de paciente analizate este suficient de mare pentru o analiză statistică corectă.

Boala parodontală este o afecţiune care include gingivita drept variantă mai uşoară, o inflamaţie reversibilă a ţesuturilor moi adiacente dinţilor, dar şi parodontita, forma mai severă a bolii, care în esenţă este reprezentată de distrugerea ţesuturilor moi, a osului alveolar şi a celorlalte structuri de susţinere a dentiţiei. Se consideră că lipopolizaharidele şi ADN-ul conţinut de bacteriile din placa dentară prezentă la pacientele cu parodontită sunt responsabile pentru producerea citokinelor proinflamatorii şi a inflamaţiei sistemice cronice. În plus, aceste citokine proinflamatorii pot determina recrutarea de neutrofile hiperresponsive, care cresc producţia de specii reactive de oxigen. Astfel, se poate specula că unul dintre mecanismele care conectează cele două afecţiuni, endometrioza şi parodontita, este reprezentat de inflamaţ̧ia sistemică cronică întâlnită în ambele boli, cu posibilitatea potenţării reciproce. În plus, ambele afecţiuni au fost asociate cu o dereglare a răspunsului imun. Astfel, în endometrioză a fost descrisă scăderea activităţii celulelor natural killer şi a citotoxicităţii împotriva celulelor endometriale, rezultând toleranţa răspunsului imun faţă de implanturile endometriozice, dar, în acelaşi timp, fiind asociată cu un risc crescut de afecţiuni autoimune (16). Boala parodontală este, de asemenea, considerată o afecţiune cu componentă autoimună, aspect semnalat încă din 1965 de către Brandtzaeg şi Kraus (17). În plus, este considerată un posibil trigger pentru afecţiuni cu patogenie autoimună precum poliartrita reumatoidă. O posibilă explicaţie este expunerea la bacteriile din placa dentară, ca posibilă sursă de apariţie a autoanticorpilor. În concluzie, în prezenţa unei dereglări a răspunsului imun, precum în endometrioză, expunerea la patogenii parodontali poate conduce la apariţia unui răspuns autoimun care să determine sau să amplifice procesele inflamatorii parodontale. În schimb, inflamaţia parodontală poate avea răsunet sistemic, contribuind la inflamaţia sistemică cronică din endometrioză. 


\section{Sindromul ovarului polichistic şi parodontita}

Sindromul ovarelor polichistice (SOPC) este o afecţiune cu determinism genetic, al cărei tablou clinic include anovulaţie cronică, hiperandrogenism şi aspectul ecografic de ovar polichistic. Este cea mai frecventă tulburare endocrină la femeile de vârstă reproductivă, cu o prevalenţă variind de la $6,5 \%$ la $8 \%$ (11). Asocierea între SOPC şi parodontită a fost descrisă prima dată de Dursun în 2011 (4). Ambele afecţiuni sunt caracterizate de o inflamaţie sistemică cronică, fiind posibil ca aceasta să fie veriga patogenică comună responsabilă pentru asocierea celor două condiţii. Această ipoteză este susţinută de constatarea nivelului crescut al citokinelor proinflamatorii, al proteinei $\mathrm{C}$ reactive şi a leucocitelor la ambele categorii de paciente. În plus, studiul lui Ozcaka şi colab. (6) a arătat că nivelul IL6 este crescut în serul, saliva şi lichidul crevicular la pacientele cu SOPC şi gingivită, sugerând că asocierea celor două afecţiuni acţionează sinergic asupra inflamaţiei sistemice şi gingivale. În schimb, IL-17E a fost scăzută la pacientele cu SOPC şi gingivită (7). În aceste studii, a fost observată o corelaţie între parametrii parodontali şi nivelul seric al interleukinelor IL-17A şi IL-17F (7), TNF- $\alpha$, receptori de TNF- $\alpha$ şi nivelul salivar de IL6 la pacientele cu SOPC şi gingivită $(6,7)$. Relaţia dintre SOPC şi patologia parodontală este probabil bidirecţională. Astfel, proliferarea bacteriană de la nivelul plăcii dentare la pacienţii cu afecţiuni parodontale conduce la o inflamaţie locală, dar şi sistemică, agravând astfel inflamaţia sistemică din SOPC. Similar, inflamaţia sistemică din SOPC poate conduce la creşterea nivelului citokinelor proinflamatorii şi al altor mediatori ai inflamaţiei la nivelul structurilor parodontale.

MMPs sunt enzime proteolitice eliberate de către neutrofilele prezente la locul inflamaţiei care determină degradarea matricei extracelulare ca răspuns la infecţia bacteriană în parodontită. Nivelul crescut al MMP-8 în ser şi salivă la pacientele cu SOPC şi gingivită poate fi implicat atât în procesele distructive din gingivită/parodontită, cât şi în dereglarea funcţiei ovariene, întâlnită în SOPC, deoarece atât steroidogeneza ovariană, cât şi ovulaţia implică o remodelare tisulară continuă în care MMPs sunt implicate. În plus raportul MMP/TIMP 1 crescut la pacientele cu ambele afecţiuni sugerea- ză o capacitate redusă de atenuare a acţiunii MMPs la aceste paciente.

Este, de asemenea, posibil ca pacientele cu SOPC să aibă o populaţie bacteriană particulară. Acest aspect este sugerat de creşterea proporţiei anumitor bacterii în flora orală a pacientelor cu SOPC şi gingivită, dar şi a nivelului seric al anticorpilor îndreptaţi împotriva anumitor bacterii. Se observă astfel o modificare cantitativă a florei microbiene orale şi o exacerbare a răspunsului sistemic la membrii selectivi ai acestei comunităţi microbiene induse de SOPC. Un factor favorizant pentru modificarea florei microbiene în SOPC ar putea fi anomaliile hormonale asociate cu această afecţiune. Astfel, acumularea estrogenilor în ţesuturile parodontale a fost demonstrată a furniza nutrienţii necesari creşterii bacteriene (18). Este de asemenea posibil ca o receptivitate crescută a ţesuturilor la estrogeni să predispună aceste paciente la apariţia complicaţiilor gingivale. Acest aspect este susţinut de o prezentare de caz care a raportat că prezenţa gingivitei a fost asociată cu prezenţa receptorilor pentru estrogeni, dar nu şi pentru progesteron la o pacientă cu SOPC şi gingivită comparativ cu cele fără gingivită (14). În schimb, lipopolizaharidele produse de flora parodontală pot conduce la creşterea citokinelor proinflamatorii (19), contribuind astfel la agravarea inflamaţiei cronice din SOPC.

Efectul intervenţiilor terapeutice pentru cele două afecţiuni sugerează o relaţie bidirecţională între SOPC şi parodontită, cu capacitatea de a se potenţa reciproc. Astfel, s-a constatat că pacientele nou diagnosticate cu SOPC au avut afectare parodontală mai frecventă şi mai severă comparativ cu pacientele tratate cu SOPC (12). De asemenea, nivelul inflamaţiei sistemice a fost mai mare la pacientele netratate, sugerând că modalitaţile terapeutice de influenţare a inflamaţiei sistemice în SOPC pot contribui la reducerea patologiei parodontale. În schimb, asocierea tratamentului nonchirurgical pentru parodontită la tratamentul medicamentos pentru SOPC a contribuit la reducerea inflamaţiei sistemice la pacientele cu SOPC. În consecinţă, ameliorarea oricăreia dintre cele două afecţiuni poate avea un impact pozitiv asupra celeilalte, $\mathrm{cu}$ implicaţii terapeutice şi patogenice (20).

Date în susţinerea acestei ipoteze sunt oferite de studiile care au arătat că tratamentul laser al paro- 
dontopatiilor este asociat cu scăderea nivelului citokinelor proinflamatorii la pacienţii cu afecţiuni coronariene $(21,22)$, iar tratamentul nonchirurgical al parodontitei îmbunătăţeşte valorile glicemiei la pacienţii cu diabet zaharat.

\section{CONCLUZII}

Datele actuale sugerează existenţa unei asocieri între patologia parodontală şi afecţiuni precum endometrioza sau SOPC. Mecanismele responsabile pentru această asociere sunt prea puţin cunoscute, necesitând aprofundare prin studii experimentale şi clinice. Pe baza informaţiilor actuale, am putea considera că aceste afecţiuni sunt conectate printr-o inflamaţie sistemică cronică şi se pot potenţa reci-

\section{BIBLIOGRAFIE}

1. Burt B. Position paper: Epidemiology of periodontal diseases. J Periodontol 2005; 76:1406-19.

2. Kavoussi SK, West BT, Taylor GW, Lebovic DI. Periodontal disease and endometriosis: Analysis of the National Health and Nutrition Examination Survey. Fertil Steril. 2009 Feb;91(2):335-42.

3. Thomas V, Uppoor AS, Pralhad S, Naik DG, Kushtagi P. Towards a Common Etiopathogenesis: Periodontal Disease and Endometriosis. J Hum Reprod Sci 2018 Jul-Sep; 11(3):269-273.

4. Dursun E, Akalin FA, Guncu GN, Cinar N, Aksoy DY, Tozum TF et al. Periodontal disease in polycystic ovary syndrome. Fertil Steril 2011; 95:320-323.

5. Rahiminejad ME, Moaddab A, Zaryoun H, Rabiee S, Moaddab A, Khodadoustan A. Comparison of prevalence of periodontal disease in women with polycystic ovary syndrome and healthy controls. Dental Res J 2015; 12:507-512.

6. Özçaka Ö, Ceyhan BÖ, Akcali A, Biçakci N, Lappin DF, Buduneli N. Is there an interaction between polycystic ovary syndrome and gingival inflammation? J Periodontol. 2012 Dec;83(12):1529-37.

7. Özçaka Ö, Buduneli N, Ceyhan BO, Akcali A, Hannah V, Nile C Lappin DF. Is interleukin-17 involved in the interaction between polycystic ovary syndrome and gingival inflammation? J Periodontol. 2013 Dec;84(12):1827-37.

8. Akcali A, Bostanci N, Ozcaka O, Ozturk-Ceyhan B, Gumus P, Tervahartiala $T$ et al. Elevated matrix metalloproteinase-8 in saliva and serum in polycystic ovary syndrome and association with gingival inflammation. Innate Immunity 2015; 21: 619-625.

9. Akcalı A, Bostanci N, Özçaka Ö, Gümüş P, Öztürk-Ceyhan B, Tervahartiala T, Husu H, Buduneli N, Sorsa T, Belibasakis GN. Gingival Inflammation and Salivary or Serum Granulocyte-Secreted Enzymes in Patients With Polycystic Ovary Syndrome. J Periodontol. 2017 Nov;88(11):1145-1152.

10. Varadan M, Gopalkrishna P, Bhat PV, Kamath SU, Kumar S. Influence of polycystic ovary syndrome on the periodontal health of Indian women visiting a secondary health care centre. Clin Oral Investig. 2019 Aug;23(8):3249-3255.

11. Akcalı A, Bostanci N, Özçaka Ö, Öztürk-Ceyhan B, Gümüş $P$, Buduneli N, Belibasakis GN. Association between polycystic ovary syndrome, oral microbiota and systemic antibody responses. PLoS One. 2014 Sep 18;9(9):e108074.

12. Porwal S, Tewari S, Sharma RK, Singhal SR, Narula SC. Periodontal status and high-sensitivity C-reactive protein levels in polycystic proc. $\mathrm{Cu}$ toate acestea, dacă parodontopatia este cauza sau efectul este greu de spus în acest moment. Aceste detalii patogenice sunt esenţiale din perspectiva terapeutică, permiţând clinicianului să poată interveni eficient asupra factorilor cauzali pentru ameliorarea consecinţelor. În absenţa acestor informaţii, este prudent să se acorde importanţă identificării şi tratării patologiei parodontale la pacientele cu endometrioză sau SOPC, în special dacă asociază şi infertilitate, pentru îmbunătăţirea rezultatelor tratamentului.

\section{Mențiune}

Toţi autorii au contribuţie egală la realizarea acestui articol.

Conflict of interest: none declared Financial support: none declared

ovary syndrome with and without medical treatment. J Periodontol. 2014 Oct;85(10):1380-9.

13. Deepti, Tewari S, Narula SC, Singhal SR, Sharma RK. Effect of Non-Surgical Periodontal Therapy Along With Myo-Inositol on High-Sensitivity C-Reactive Protein and Insulin Resistance in Women With Polycystic Ovary Syndrome and Chronic Periodontitis: A Randomized Controlled Trial. J Periodontol. 2017 Oct;88(10):9991011.

14. Asnani KP, Hingorani D, Kheur S, Deshmukh V, Romanos GE. Expression of nuclear receptors of gingiva in polycystic ovarian syndrome: A preliminary case study. Aust Dent J. 2014 Jun;59(2):252-7.

15. Pavlatou A, Tsami A, Vlahos N, et al. The effect of in vitro fertilization on gingival inflammation according to women's periodontal status: clinical data. J Int Acad Periodontol. 2013;15:36-42.

16. Shigesi N, Kvaskoff M, Kirtley S, Feng Q, Fang H, Knight JC, Missmer SA, Rahmioglu N, Zondervan KT, Becker CM. The association between endometriosis and autoimmune diseases: $\mathrm{A}$ systematic review and meta-analysis. Hum Reprod Update. 2019 Jul; 25(4): 486-503.

17. Brandtzaeg P, Kraus FW. Autoimmunity and periodontal disease. Odontol Tidskr. 1965 Jun 30;73:281-393.

18. Raber-Durlacher JE, van Steenbergen TJ, Van der Velden U, de Graaff J, Abraham-Inpijn L. Experimental gingivitis during pregnancy and post-partum: Clinical, endocrinological, and microbiological aspects. J Clin Periodontol. 1994 Sep; 21(8):549-58.

19. Lindemann RA, Economou JS, Rothermel H. Production of interleukin-1 and tumor necrosis factor by human peripheral monocytes activated by periodontal bacteria and extracted lipopolysaccharides. J Dent Res. 1988 Aug; 67(8):1131-5.

20. Kellesarian SV. Association between periodontal disease and polycystic ovary syndrome: A systematic review. International Journal of Impotence Research (2017) 29, 89-95.

21. Javed F, Kellesarian SV, Al-Kheraif AA, Ranna V, Qadri T, Yunker M et al. Effect of Nd:YAG laser-assisted non-surgical periodontal therapy on clinical periodontal and serum biomarkers in patients with and without coronary artery disease: A short-term pilot study. Lasers Surg Med 2016; 48:929-935.

22. Offenbacher S, Beck JD. A perspective on the potential cardioprotective benefits of periodontal therapy. Am Heart J 2005; 149:950-4. 